\title{
Obituary
}

\section{Mr. C. E. Stromeyer}

$\mathrm{H}^{4}$ ALF a century ago the practices used in the design and construction of industrial boilers left much to be desired in the way of scientific treatment, and it is no exaggeration to say that Charles Edmond Stromeyer, as chief engineer to the Manchester Steam Users' Association, was a leading spirit in the process of transforming the existing art into something approaching an exact science. The reason is not difficult to find, since he possessed an inborn capacity for investigation and research, to which was added the experience gained during seventeen years as an engineer surveyor to Lloyd's Register of Shipping. During that persistent endeavour, which occupied thirty years, the city of his adoption was a centre of interest for those engaged on the construction and maintenance of boilers, for engineers from distant lands frequently called upon him-and the pilgrimage continued after the year of retirement, in 1928. For this reason, a wide circle of friends must have welcomed the honorary degree of Dr. Ing. that was conferred last year by the Technische Hochschule at Aachen on its old graduate.

It is strange to recall that Stromeyer's apprenticeship was terminated due to an incapacity for further manual labour, since up to a few weeks before his death at Bad Nauheim, on July 23, in his eightieth year, he daily attacked the work that lay before him in the study and the laboratory. As a further indication of this unceasing activity of mind and body, it may be remarked that the manuscript of his "Unity in Nature", which may still be read with much pleasure and profit, was written en route during bi-weekly journeys between Manchester and London in the years preceding the War, when he was much occupied on professional and scientific affairs in London. Not the least important of those interests were matters connected with the foundation of the National Physical Laboratory.

Since he belonged to a generation that regarded education mainly as a training for independent thinking, Stromeyer's contributions to the proceedings of the Royal Society and our senior engineering and naval institutions almost invariably formed milestones by the way of progress in his sphere of interests. The ground included in that sphere was extensive, as he made the first direct determination of Poisson's ratio, used his interference strain indicator to measure the stresses on ships and the strains on railway bridges in the 'eighties, and contributed an instructive paper, on map-projection, to the International Geographical Congress held at Berlin in 1900. His work on the fatigue of metals is of outstanding merit, and the involved investigations doubtless gave rise to an original contribution presented in 1907 to the Manchester Literary and Philosophical Society, in which the atomic weights of the elements were expressed in the form of a harmonic series. In view of such a wide and deep knowledge of natural philosophy, it is in the nature of things that his "Marine Boiler Management and Construction" should have attained a sixth edition, apart from foreign translations of the volume.

With his intense devotion to work, anything short of transparent honesty met with Stromeyer's strongest disapproval, and he considered no weapon too heavy to handle in the defence of what appeared to be the right course of conduct. That characteristic must have served him well during the War period, in undertaking the exacting duty of examining and reporting on the safety of secondhand boilers that would not have been used in other circumstances.

To those who were privileged to know him intimately, Stromeyer's cultured and attractive outlook on life was a constant source of pleasure, as the labour of the day never seemed to tire the boyish spirit that was the deep-seated source of his activity. The welfare of his assistants was as real a concern to him as was their success in professional affairs, and they, along with many others, will place him in that small company of whom it may be said that they were "Servants upon horses, and princes walking as servants upon the earth". In that role his charming wife bore him faithful company. D. L-T.

\section{Dr. Arthur Bramley}

THE death of Dr. Arthur Bramley on July 19 deprives chemical and metallurgical science of a brilliant worker. Born in 1878, he was forced to leave school early, and served a full apprenticeship to the hosiery trade. He commenced his technical education in Halifax Technical College, and in 1904 obtained a staff appointment there. This was followed in 1906 by a national scholarship of the Royal College of Science where he graduated, carried out research work and finally became private research assistant to Prof. J. C. Philip. With the latter he conducted a number of researches on the physicochemical properties of solutions and ionic complexes the results of which are published in the Journal of the Chemical Society. He then proceeded to investigate the physical properties of binary liquid mixtures, for which work he was awarded the degree of D.Sc.

The second phase of Dr. Bramley's service to science commenced with his appointment to the technical staff of British Dyestuffs Corporation at Huddersfield, where he remained until he was appointed to take charge of the Department of Pure and Applied Science, Loughborough College, in 1918. At Loughborough he commenced a long series of researches on the diffusion of non-metallic elements into iron and steel and was able to show that the mechanism of this diffusion follows the normal physico-chemical course. These researches, published over a period of fifteen years, obtained for 
him the award of the Carnegie Gold Medal in 1929.

Apart from his research work, Dr. Bramley was an enthusiastic teacher and had been instrumental in building up an active Pure Science Department in Loughborough College; his untimely end cut short a career which had promise of even greater fruition.

$W_{E}$ regret to announce the following deaths:

Dr. R. W. Brock, dean of the Faculty of Applied Seience in the University of British Columbia, known for his work in economic geology, on July 31, aged seventy-one years.

Prof. B. L. Robinson, emeritus professor of systematic botany in Harvard University, an authority on the classification of American sperm. atophytes, on July 27, aged seventy years.

Mr. W. T. H. Spicer, formerly first ophthalmic surgeon at St. Bartholomew's Hospital, known for his work in connexion with the teaching of ophthalmology, on August 8, aged seventy-four years.

Mr. A. H. Swinton, a well-known naturalist, author of "Insect Variety, its Propagation and Distribution", on July 25, aged ninety-one years.

\section{News and Views}

\section{Archæology in the Cambridge Fens}

IN another column of this issue of NATURE (see p. 304) there appears a brief account of the results of tree pollen and vegetation analyses of peat deposits in the Cambridgeshire Fens. The borings by which the material for these was obtained were made in connexion with an archæological excavation undertaken with the object of establishing the stratigraphical position of prehistoric cultures of mesolithic and bronze age, of which surface indications appeared on this site at Peacock's Farm, Shippea Hill, Cambridge. The archæological results, based on the stratigraphic evidence, taken in conjunction with the evidence of the botanical investigation, have a farreaching significance. A succession of three cultural horizons has been established, Early Bronze Age, Neolithic and Late Tardenoisian. The demonstration of such a succession on one site in a single vertical section is unique. Further, the association of each with a definite forest growth and vegetation contexta microlithic industry is here found in a peat deposit for the first time in Britain-opens the way to a number of precise chronological and cultural correlations. Hereby this Late Tardenoisian site is linked. up with other finds in Britain, such as that at Skipsea, Yorks, and with Continental sites, such as Maglemose, Mullerup and Kunda.

IN other directions, also, this excavation has established important criteria for future investigation. Thus Neolithic $A$, the Windmill Hill culture, appears in this part of the country for the first time, not far removed from sites of Neolithic $B$, "Peterborough", finds. The application of the method of pollen analysis to the latter, when occasion arises, no doubt at an early date, should settle definitely the, at present, uncertain chronological relations of the two cultures. Mr. J. G. D. Clark's skilful reconstruction of the history of the site-a history of shrinkage of the area of settlement from period to period owing to the encroachment of the peat, with long periods of inactivity intervening-is an achievement which will hold a permanent place in the history of archæological investigation.

\section{Excavations at Maiden Castle, Dorchester}

Excavations have been resumed at Maiden Castle, Dorchester, under the direction of Dr. R. E. Mortimer Wheeler, the initial objective being the investigation of the history of the ramparts. Digging at a point where the rampart rises to a height of fifty feet above the external ditch has revealed that the structure was composed of a core of carefully built up chalk rubble, faced on the inner side, covered with a layer of clay and chalk and surmounted by a parapet of limestone. The parapet was partially destroyed in ancient times, and eventually replaced by a timber palisade of which the socket holes have been found at a higher level. This palisade was constructed of stout timber posts at a distance of four or five feet apart and doubtless joined by woven hurdles. A cutting which has been made through the main defence shows evidence of five prehistoric periods in the history of the earthwork, the earliest being a palisaded bank of about ten feet, and culminating in an elaborate structure of masonry rising twenty feet above the internal camp. Beneath the original turf line a stone age factory floor was uncovered, on which were innumerable flakes from implement making, and a few scrapers and other tools. On an adjacent site a series of pits has been found, of which one is nine feet deep. These pits contained prehistoric pottery and a number of querns for grinding corn. Nearby was a group of ten loom-weights of chalk ; and in the centre of this site post holes indicate the position of a large circular hut twenty-one feet in diameter. Finally, at the east gate of the camp three roads of late-Roman and post-Roman date have been examined and prehistoric road level has been reached.

\section{Unknown Papua}

Some further particulars of the hitherto unknown people found in Papua by $\mathrm{Mr}$. J. G. Hides (see NATURE, August 17, p. 251) are given in extracts from the official report and an article by the Australian correspondent of The Times in the issue of August 14. The report stresses the interest of the people in afforestation, the exactness of the division of the 